\title{
Reports on the presence of the milkfish Chanos chanos (Forsskål, 1775) (Gonorynchiformes: Chanidae) in the Shatt al-Arab River, Basrah and in the marine waters of Iraq, with notes on its tolerance to freshwater
}

Audai Mohamed Qasim¹, Falah Marouf Mutlak ${ }^{1}$, Abbas Jassim Al-Faisal ${ }^{1}$ \& Laith Abd Jalil Jawad ${ }^{2}$

1 Department of marine vertebrates, Marine Science Centre, University of Basrah, Basrah, Iraq.

2 Pokeno, Auckland 2417, New Zealand.

\section{Correspondence}

LA. Jawad

E-mail: laith_jawad@hotmail.com

Received: 9 April 2019

Accepted: 2 December 2019

Published on-line: 18 December 2019

\section{Resumen}

Registro de la presencia del sabalote Chanos chanos (Forsskäl, 1775) (Gonorynchiformes: Chanidae) en el río Shatt al-Arab/ Arvand, Basora y las aguas marinas de Irak, con notas sobre su tolerancia al agua dulce

En este estudio, se describen dos especímenes de sabalote Chanos chanos (LT 380 y $390 \mathrm{~mm}$ ) en aguas marinas de Irak y otros cuatro del río Shatt al-Arab/Arvand en la ciudad de Abu alKhaseeb, al sur de Irak (LT 310-312,5 mm). Ambas localidades significan una extensión del rango de distribución para el sabalote y la de Abu al-Khaseeb representa la distancia máxima para que esta especie ascienda por el río. Se proporcionan y comparan datos morfométricos y merísticos con especímenes de otras partes del mundo. Se incide sobre la tolerancia en hábitats dulceacuícolas a $65 \mathrm{~km}$ del mar.

Palabras clave: Extensión de rango; Abu al-Khaseeb; Ocurrencia; Tolerancia al agua dulce; Chanidae; Basora.

\begin{abstract}
In the present study, two specimens of the milkfish Chanos chanos (380 and $390 \mathrm{~mm} \mathrm{TL}$ ) are described from the marine waters of Iraq and another four specimens from the Shatt al-Arab River at Abu alKhaseeb City, south of Iraq (310-312.5 mm TL). Both localities represent a new range extension for the milkfish, but those from Shatt al-Arab River represent the maximum distance for this species to ascend. Morphometric and meristic data are provided and compared with other specimens of this species from other parts of the world. A note is given about the tolerance to freshwater habitats about $65 \mathrm{~km}$ away from the sea.
\end{abstract}

Key words: Range extension; Abu al-Khaseeb; Occurrence; Freshwater tolerance; Chanidae; Basrah. 


\section{Introduction}

The family Chanidae, order Gonorynchiformes, comprises a single species: the milkfish, Chanos chanos. Descriptions of milkfish have been given by numerous authors (e.g., Herre \& Mendoza 1929, Hardenberg 1953, Fischer \& Whitehead 1974), but Bagarinao (1994) suggested that juvenile milkfish may represent a different species, due to differences in shape.

The milkfish is a marine inhabitant and an efficient osmoregulator (Ferraris et al. 1988). It is widely distributed throughout the tropical and subtropical Indo-Pacific (Bagarinao 1994) and is an important species to the aquaculture industry in several countries such as Indonesia, Philippines, and Taiwan. It has a natural distribution, but is also commercially cultured in fresh, brackish, and oceanic waters as well as in hypersaline lagoons (Crear 1980).

In the last few decades, several studies have been published on the marine fish fauna of Iraq (Khalaf 1961, Mahdi 1971, Al-Daham 1982, AlHassan \& Al-Badri 1986, Al-Hassan \& Miller 1987; Hussain et al. 1988, Hussain \& Naama 1989, Fricke \& Al-Hassan 1995). Nevertheless, it still is incompletely investigated and a lot of taxonomic work remains to be done (Jawad 2012).

Although the milkfish $C$. chanos has been reported from several countries in the Arabian Gulf area and the neighbouring regions, no report nor record of this species exists on its presence in the marine waters of Iraq or in a freshwater environment of the Shatt al-Arab River. Therefore, the aim of the present study is to record the milkfish from two ecologically different habitats, the marine waters of Iraq and the Shatt al-Arab River, Basrah, Iraq.

\section{Material and methods}

Two specimens of milkfish (380, $390 \mathrm{~mm} \mathrm{TL})$ were collected from the marine waters of Iraq (29 47' 08.90" N 48 45' 01.10" E) (Station 1) and four specimens (310-390 mm TL) from the Shatt al-Arab River at Abu al-Khaseeb City $\left(30^{\circ}\right.$ $28^{\prime}$ 07.84" N $48^{\circ} 02^{\prime} 16.09^{\prime \prime}$ E) (Station 2) on the 13th of November 2017 and the 10th of June 2017, respectively (Fig. 1). Specimens obtained from the marine waters were collected by a set net (Fig. 2A), while those obtained from the Shatt al- arab River (Fig. 2B) were collected by fishermen operating in the area using $240 \times 10 \mathrm{~m}$ drifting gill nets of $35 \times 35 \mathrm{~mm}$ mesh size. Meristic counts were made and measurements taken using Vernier calipers and recorded to the nearest 0.1 $\mathrm{mm}$, according to the methods of Fischer \& Bianchi (1984). The specimens were identification followed Fischer \& Bianchi (1984). Body morphometrics are shown in table 1. Eschmeyer (2018) and Fricke (2015) were used to determine the taxonomic status of the species and the spelling of the name. The specimens were fixed in $10 \%$ formaldehyde solution, then preserved in $70 \%$ ethanol, and deposited in the ichthyological collection of the Marine Science Centre, University of Basrah.

\section{Results}

All specimens collected from all localities show the following set of characters: elongated and moderately compressed body, no scutes along belly; small mouth; absence of teeth; small tubercles on lower jaw; presence of four branchiostegal rays; dorsal fin located at about midpoint of body; anal fin short and originated posterior to dorsal fin base; small scales on body; pectoral fins falcate; line passing through tip of mouth and middle of eye also passes through forked point of caudal fin thus dividing fish body into equal halves; line passing through tip of mouth and origin of dorsal fin also passes just below upper edge of eye; body with olive green colour at back, with silvery flanks; all fins with dark margins. Specimens from the Shatt al-Arab River with yellowish pectoral and pelvic fins, and white anal fin.

\section{Discussion}

The two specimens collected from the marine waters of Iraq have 380 and $390 \mathrm{~mm}$ TL, while those from the Shatt al-Arab River have 310 and 312.5 mm TL. All four specimens are smaller than the maximum size (1800 $\mathrm{mm}$ TL) reported for this species by Lieske \& Myers (1994). The other morphometrics and meristic characters are similar to those given by Fischer \& Bianchi (1984), except for the yellowish colour of the pectoral and pelvic fins and for the overall white colour of the anal fin in the specimens from the Shatt al-Arab River. Bagarinao (1994) suggested that milkfish 


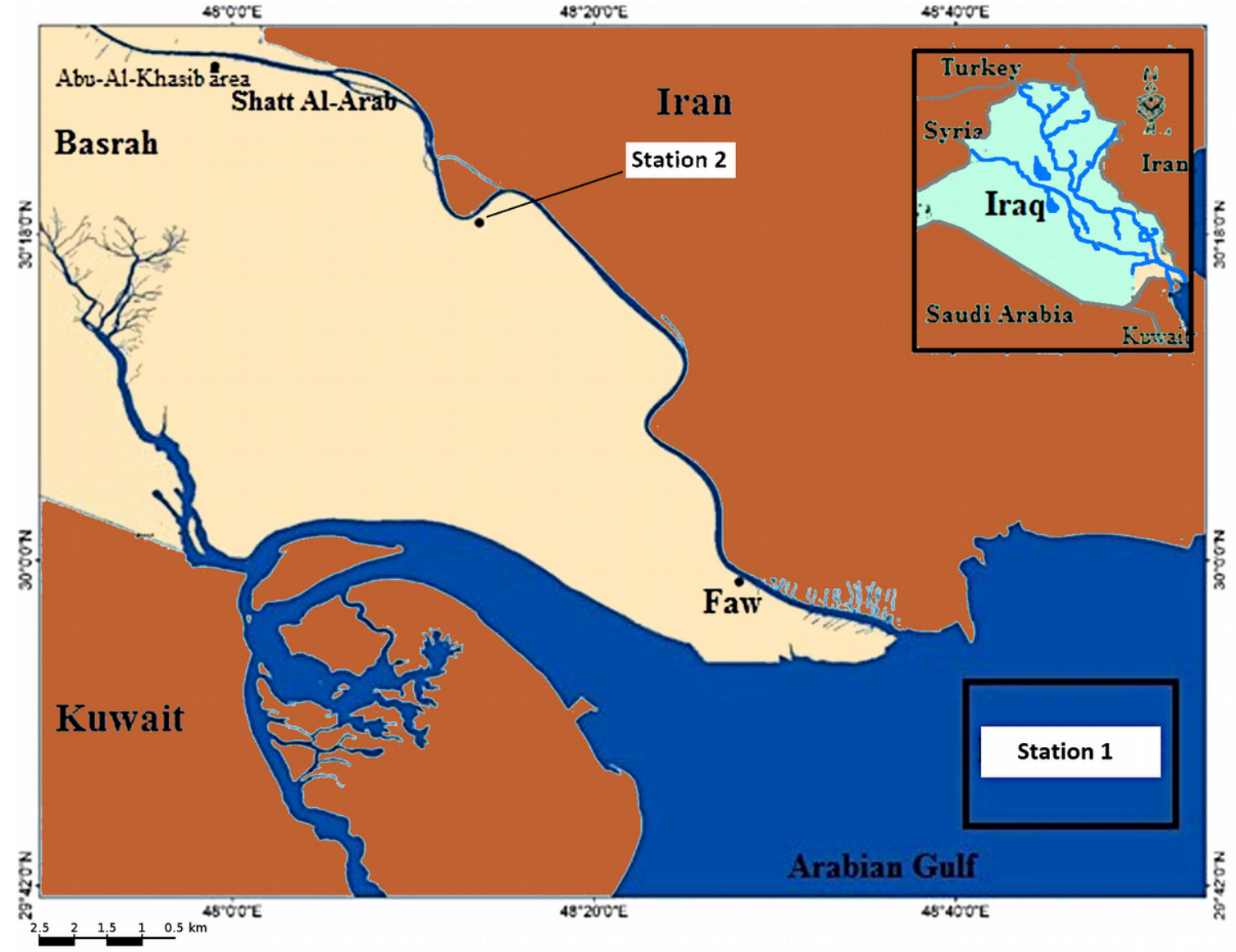

Figura 1. Mapa mostrando las localiades de muestreo. Esatción 1: Aguas marinas de Irak; estación 2: río Shatt al-Arab/Arvand en la ciudad de Abu al-Khaseeb.

Figure 1. Map showing the sampling localities. Station 1: Marine waters of Iraq; station 2: Shatt al-Arab River at Abu al-Khaseeb City station.

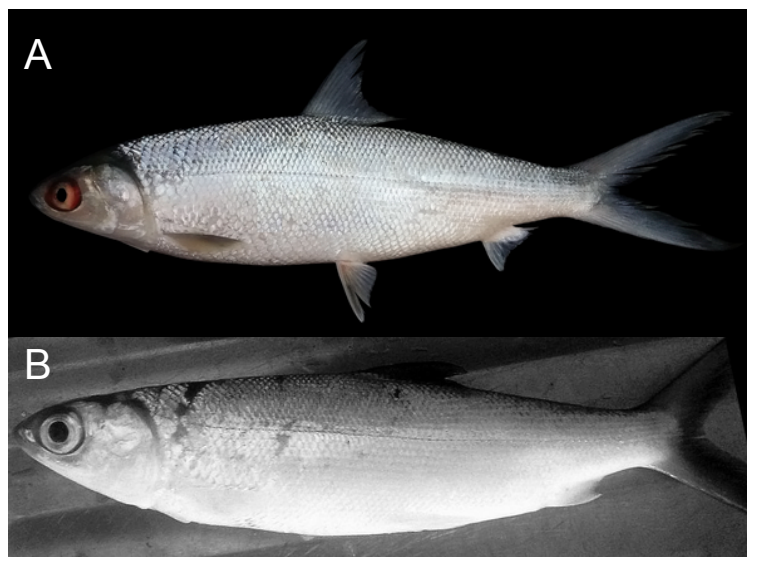

Figura 2. Chanos chanos. A: Capturado en las aguas marinas de Irak (LT $390 \mathrm{~mm}$ ); B: Capturado en el río Shatt al-Arab/Arvand, en la ciudad de Abu al-Khaseeb (LT 312,5 mm).

Figure 2. Chanos chanos. A: Collected from the marine waters of Iraq (390 mm TL); B: Collected from the Shatt al-Arab River at Abu al-Khaseeb City (312.5 mm TL).

might have an unusual colouration such as a red head, red fins and a brilliant-blue dorsal surface, although no information is available about the ori- gin of this colour variation for the species. The unusual fin colouration in our specimens from the Shatt al-Arab River will be added to that already reported for the milkfish.

Chanos chanos is the only species within the family Chanidae, therefore, no confusion with any congener based on morphological characters is possible. Fischer \& Bianchi (1984) stated that milkfish can easily be confused with species of the family Clupeidae, but the latter are generally smaller, have scutes along the abdomen, but no lateral line, and usually possess six or seven branchiostegal rays versus only four in $C$. chanos. The milkfish might also be mistaken for Megalops cyprinoides as the latter has large scales, about 30 to 40 in the lateral line, a filamentous last dorsal fin ray and a bony gularplate between the branches of the lower jaw.

The milkfish has a wide range of distribution in the North West Indian Ocean, it has been reported from coasts of different countries in the 
Arabian Gulf area (Froese \& Pauly, 2018, GBIF 2018). The catches further north in the Arabian Gulf and in the Shatt al-Arab River represent a range extension in this part of the world.

Although C. chanos is known to ascend rivers (Froese \& Pauly 2018), this is usually limited to less than 10 miles $(16.2 \mathrm{Km})$, which represents the area very close to the estuary of a river (Whitehead 1960, Coates 1987, Chen et al. 2004). Abu al-Khaseeb City, where the two specimens were collected, is situated at $64.4 \mathrm{~km}$ north of AlFaw City, where the estuary of the Shatt al-Arab River is located. This shows, that milkfish can ascend far into the freshwater system, up to four times further than reported to date, which is considered a new tolerance to freshwater.

The environmental changes along the Arabian Gulf may halt the distribution of certain species that are unable to adapt to a wide range of salinity and temperature. In this region until now, the milkfish was reported from neighbouring Kuwaiti waters (Carpenter et al. 1997). As far as the present author know, there exist no reports of this species ascending Iranian rivers although Abu alKhaseeb City is situated further north of the junction of the Karun River with the Shatt al-Arab River. Esmaeili et al. $(2010,2017)$ showed that $C$. chanos ascends rivers in the Hormuz and Makran basins located in the southern part of the Arabian Gulf and the Sea of Oman, respectively. Therefore, this study is important in providing new evidence of the milkfish ascending a freshwater body in the north of the Arabian Gulf.

The deficiency of earlier records of this species from the Arabian Gulf may be biased by the lack of ichthyological surveys in the region or may be due to its recent arrival in the area. More generally, the existence of such a noteworthy species in the freshwater system and in the Iraqi marine waters once again highlights our limitations in monitoring the arrival of invasive species in the marine environment.

\section{Acknowledgements}

Our sincere thanks are due to the Marine Science Centre, University of Basrah for using their laboratory facilities. Our sincere thanks are due to Kristiaan Hoedemakers, Royal Belgian Institute of Natural Sciences (RBINS), Vautierstraat, Brussels, Belgium for reading the manuscript.

\section{References}

Al-Daham NK. 1982. Ichthyofauna of Iraq and the Arab Gulf: A check-list. Basrah Natural History Publication 4: 1-102.

Al-Hassan LAJ \& Al-Badri MEH. 1986. First record of some fishes from Khor al-Zubair, Khor Abdullah and Shatt al- Arab, Basrah, Iraq. Cybium 10: 295-297.

Al-Hassan LAJ \& Miller PJ. 1987. Rhinogobius brunneus (Gobiidae) in the Arabian Gulf. Japanese Journal of Ichthyology 33: 405-408.

Bagarinao T. 1994. Systematics, distribution, genetics and life history of milkfish, Chanos chanos. Environmental Biology of Fishes 39: 23-41.

Carpenter KE, Krupp F, Jones DA \& Zajonz U. 1997. Living marine resources of Kuwait, eastern Saudi Arabia, Bahrain, Qatar, and the United Arab Emirates. FAO species identification field guide for fishery purposes. Rome: FAO.

Chen YC, Chen CY, Hwang HJ, Chang WB, Yeh WJ \& Che $\mathrm{MH}$. 2004. Comparison of the metal concentrations in muscle and liver tissues of fishes from the Erren River, southwestern Taiwan, after the restoration in 2000. Journal of Food and Drug Analysis 12: 358-366.

Coates D. 1987. Consideration of fish introductions into the Sepik River, Papua New Guinea. Aquaculture Research 18: 231-241.

Crear D. 1980. Observations on the reproductive state of milkfish populations (Chanos chanos) from hypersaline ponds on Christmas Island (Pacific Ocean). Proceedings of the World Mariculture Society 11: 548-566

Eschmeyer WN. (Ed.) 2018. Catalog of fishes, electronic version (20 December 2017). Internet publication, San Francisco (California Academy of Sciences). Available at http://research.calacademy.org/research /lchthyology/Catalog/fishcatmain.asp (accessed on 01-IV-2019).

Esmaeili HR, et al. 2010. Annotated checklist of the freshwater fishes of Iran. Zoosystematica Rossica 19: 361-386.

Esmaeili H R, et al. 2017. Review and updated checklist of freshwater fishes of Iran: Taxonomy, distribution and conservation status. Iranian Journal of Ichthyology 4(Suppl. 1): 1-114.

Ferraris RP, Almendras JM \& Jazul AP. 1988. Changes in plasma osmolality and chloride concentration during abrupt transfer of milkfish (Chanos chanos) from seawater to different test salinities. Aquaculture 70: 145-157

Fischer W \& Bianchi G. (eds.) 1984. FAO species identification sheets for fishery purposes. Western Indian Ocean (Fishing area 51). Volume 4. Family Scatophagidae to Trichiuridae. Rome: FAO,. Available at http://www.fao.org/docrep/009/ad468 e/ad468e00.htm (Accessed 1-IV-2018).

Fischer W \& Whitehead PJP. (eds.) 1974. FAO species identification sheets for fishery purposes, eastern Indian Ocean and western Central Pacific, Volume 1. Rome: FAO.

Fricke R. (Ed.) 2015. References in the catalog of 
fishes. Online version, updated 05 October 2014. Internet publication, San Francisco (California Academy of Sciences). Available at http://research. calacademy.org/research/lchthyology/Catalog/fishcatmain.asp (Accessed 1-IV-2018).

Fricke R \& Al-Hassan LA. 1995. Raja Pita, a New Species of Skate from the Arabian/Persian Gulf (Elasmobranchii: Rajiformes). Staatliches Museum für Naturkunde 529: 1-8

Froese R \& Pauly YD. (eds.) 2018. FishBase. World Wide Web electronic publication. Available at http://www.fishbase.org (Accessed 1-IV-2018).

GBIF 2018. Global Biodiversity Information Facility- Free and Open Access to Biodiversity Data. Available at http://www.gbif.org/ (Accessed 1-IV-2018).

Hardenberg JDF. 1953. Chanos chanos: some notes on its anatomy and physiology. Indo-Pacific Fisheries Council Special Publication 2: 4450.

Herre AW \& Mendoza J. 1929. Bangus culture in the Philippine Islands. Philippine Journal of Science 38:
451-509.

Hussain NA \& Nama AK. 1989. Survey of fish fauna of Khor Al-Zubair, northwest Arabian Gulf. Marina Mesopotamica 4: 161-197

Hussain NA, Naama AK \& Al-Hassan LAJ. 1988. Annotated check-list of the fish fauna of Khor al-Zubair, North West of the Arabian Gulf, Iraq. Acta Ichthyologica et Piscatoria 18: 17-23.

Jawad LA. 2012. History of the study of the fish fauna of Iraq. Water Research and Management 2: 11-20.

Khalaf KT. 1961. The marine and freshwater fishes of Iraq. Baghdad: Al- Rabitta Press.

Lieske E \& Myers R. 1994. Collins Pocket Guide. Coral reef fishes. Indo-Pacific \& Caribbean including the Red Sea. London: Haper Collins Publishers.

Mahdi N. 1971. Additions to the marine fish fauna of Iraq. Iraq Natural History Museum, Special Publication No. 28, 47 pp.

Whitehead PJP. 1960. The River Fisheries of Kenya. The East African Agricultural Journal 25: 259-265.

\section{Appendix}

This article includes the table 1 as electronic supplementary information :

https://www.um.es/analesdebiologia/numeros/41/PDF/41 2019 12 Table1.pdf 